\title{
Treating muscle-specific kinase myasthenia gravis from the inside out
}

Maartje G. Huijbers, PhD, and Jan J.G.M. Verschuuren, MD, PhD

Neurol Neuroimmunol Neuroinflamm 2020;7:e646. doi:10.1212/NXI.0000000000000646

Myasthenia gravis (MG) with antibodies to muscle-specific kinase (MuSK) is an autoimmune disease of the neuromuscular junction with some remarkable characteristics. Although MuSK is expressed in all skeletal muscles, patients with this disease present with particularly cranial, bulbar, and respiratory muscle weakness, leading to a relatively high frequency of respiratory crises. ${ }^{1}$ Despite several available immunosuppressive or immunomodulatory treatments, patients with MuSK MG often retain residual muscle weakness and experience more often severe muscle atrophy than patients with the more frequent MG with acetylcholine receptor (AChR) antibodies. ${ }^{2}$ Symptomatic treatment with acetylcholinesterase inhibitors is usually ineffective or even detrimental in MuSK MG, ${ }^{1}$ although 3,4-diaminopyridine might be effective in some patients. ${ }^{3}$ Therefore, treatment of MuSK MG today still mostly relies on immunosuppressive treatment. ${ }^{1}$

At the basis of the development of fatigable muscle weakness in patients with MuSK MG is the trophic signaling cascade that enables the motor nerve terminal to instruct the muscle membrane to differentiate into a mature postsynapse. MuSK is at the heart of this signaling cascade. Several groups have shown that perturbation of MuSK signaling by binding of patients' IgG4 MuSK antibodies leads to loss of this differentiation signal (MuSK phosphorylation), subsequent synaptic disintegration, failure in neuromuscular transmission, and ultimately fatigue. ${ }^{4,5}$ The predominance of IgG4 subclass autoantibodies is particularly important, as the anti-inflammatory characteristics of this type of antibody imply that the disease mechanism, response to therapy, and possibly also the etiology are different from other forms of MG with IgG1 or IgG3 autoantibodies.

In this issue of Neurology ${ }^{\circledR}:$ Neuroimmunology \& Neuroinflammation, Huda et al. ${ }^{6}$ use the current knowledge on the pathophysiology of MuSK MG to test a new therapeutic strategy by targeting the muscle directly. Normal MuSK signaling/phosphorylation is normally halted by intracellular Rous sarcoma gene (SRC) homology 2 domain-containing phosphotyrosine phosphatase 2 (SHP2). Inhibition of this phosphatase results in spontaneous and agrin-independent MuSK phosphorylation and AChR clustering in vitro. Huda et al. tested whether an SHP2 inhibitor, NSC87877, could overcome the inhibitory effect of MuSK autoantibodies in mouse myotube cultures. The study clearly shows improved MuSK activation levels, indicated by increased MuSK phosphorylation and restoration of AChR cluster formation in MuSK autoantibodytreated myofibers. AChR clusters in myotubes are generally considered immature, as they do not express the adult epsilon subunit nor contain the complex morphology required for natural neuromuscular junction transmission. In vivo, agrin (in combination with several other extracellular proteins) is considered critical for induction of maturation of the postsynaptic structure and AChR clusters. A next exciting step will be to extend these observations in vivo and confirm whether SHP2 inhibition can induce formation and maintenance of mature postsynaptic structures also after prolonged exposure to patients autoantibodies. Downstream of kinase 7 overexpression, another form of intracellular activation of MuSK phosphorylation, was shown successful in maintaining synapses in several neuromuscular disorders. ${ }^{7}$ Huda et al. show that their SHP2 inhibitor also increased the number of AChR clusters in
Correspondence

Dr. Verschuuren

J.J.G.M.Verschuuren@lumc.nl

\section{RELATED ARTICLE}

SHp2 inhibitor protects AChRs from effects of myasthenia gravis MuSK antibody

Page e645 
downstream of kinase 7-overexpressing myotubes. A negative effect of chronic activation of MuSK through SHP2 inhibition in vivo is not expected, as chronic activation of MuSK phosphorylation with a monoclonal antibody in a mouse model for amyotrophic lateral sclerosis showed positive effects on innervation and did not show a deleterious effect. ${ }^{8}$ Importantly, SHP2 is expressed in many cell types of the human body. The authors discuss the potential off-target effects, especially the risk of tumorigenesis, and suggest that based on current knowledge, the risk of tumorigenesis is not increased.

When these technical challenges are overcome, SHP2 inhibition has the potential to become a new symptomatic treatment for patients with MuSK MG. It is tempting to speculate which other disorders with neuromuscular junction impairment may benefit from strengthening synapses from "the inside out" using SHP2 inhibitors.

\section{Study funding}

No targeted funding reported.

\section{Disclosure}

LUMC, M.G. Huijbers, and J.J.G.M. Verschuuren have applied for patents in the field of MuSK myasthenia gravis. J.J.G.M. Verschuuren has been involved in consultancies for Argenx, Alexion, and Rapharma. All reimbursements were received by the LUMC. The LUMC receives royalties for a MuSK assay. Go to Neurology.org/NN for full disclosures.

\section{Publication history}

Received by Neurology: Neuroimmunology \& Neuroinflammation October 28, 2019. Accepted in final form October 30, 2019.

\section{References}

1. Guptill JT, Sanders DB, Evoli A. Anti-MuSK antibody myasthenia gravis: clinical findings and response to treatment in two large cohorts. Muscle Nerve 2011;44:36-40.

2. Farrugia ME, Robson MD, Clover L, et al. MRI and clinical studies of facial and bulbar muscle involvement in MuSK antibody-associated myasthenia gravis. Brain 2006; 129(pt 6):1481-1492.

3. Skjei KL, Lennon VA, Kuntz NL. Muscle specific kinase autoimmune myasthenia gravis in children: a case series. Neuromuscul Disord 2013;23:874-882.

4. Koneczny I, Cossins J, Waters P, Beeson D, Vincent A. MuSK myasthenia gravis IgG4 disrupts the interaction of LRP4 with MuSK but both IgG4 and IgG1-3 can disperse preformed agrin-independent AChR clusters. PLoS One 2013;8:e80695.

5. Huijbers MG, Zhang W, Klooster R, et al. MuSK IgG4 autoantibodies cause myasthenia gravis by inhibiting binding between MuSK and Lrp4. Proc Natl Acad Sci U S A 2013;110:20783-20788.

6. Huda S, Cao M, De Rosa A, et al. SHp2 inhibitor protects AChRs from effects of myasthenia gravis MuSK antibody. Neurol Neuroimmunol Neuroinflamm 2019;7: e645. doi: 10.1212/NXI.0000000000000645.

7. Arimura S, Okada T, Tezuka T, et al. Neuromuscular disease. DOK7 gene therapy benefits mouse models of diseases characterized by defects in the neuromuscular junction. Science 2014;345:1505-1508.

8. Cantor S, Zhang W, Delestrée N, Remédio L, Mentis GZ, Burden SJ. Preserving neuromuscular synapses in ALS by stimulating MuSK with a therapeutic agonist antibody. Elife 2018;7:e34375.

9. Ohno K, Ohkawara B, Ito M. Agrin-LRP4-MuSK signaling as a therapeutic target for myasthenia gravis and other neuromuscular disorders. Expert Opin Ther Targets 2017;21:949-958. 


\title{
Neurology \\ Neuroimmunology \& Neuroinflammation
}

\author{
Treating muscle-specific kinase myasthenia gravis from the inside out \\ Maartje G. Huijbers and Jan J.G.M. Verschuuren \\ Neurol Neuroimmunol Neuroinflamm 2020;7; \\ DOI 10.1212/NXI.0000000000000646
}

This information is current as of December 12, 2019

\section{Updated Information \& Services}

References

Citations

Subspecialty Collections

Permissions \& Licensing

Reprints including high resolution figures, can be found at:

http://nn.neurology.org/content/7/1/e646.full.html

This article cites 9 articles, 2 of which you can access for free at: http://nn.neurology.org/content/7/1/e646.full.html\#\#ref-list-1

This article has been cited by 1 HighWire-hosted articles: http://nn.neurology.org/content/7/1/e646.full.html\#\#otherarticles

This article, along with others on similar topics, appears in the following collection(s):

Myasthenia

http://nn.neurology.org//cgi/collection/myasthenia

Information about reproducing this article in parts (figures,tables) or in its entirety can be found online at:

http://nn.neurology.org/misc/about.xhtml\#permissions

Information about ordering reprints can be found online: http://nn.neurology.org/misc/addir.xhtml\#reprintsus

Neurol Neuroimmunol Neuroinflamm is an official journal of the American Academy of Neurology.

Published since April 2014, it is an open-access, online-only, continuous publication journal. Copyright

Copyright $\odot 2019$ The Author(s). Published by Wolters Kluwer Health, Inc. on behalf of the American

Academy of Neurology.. All rights reserved. Online ISSN: 2332-7812.

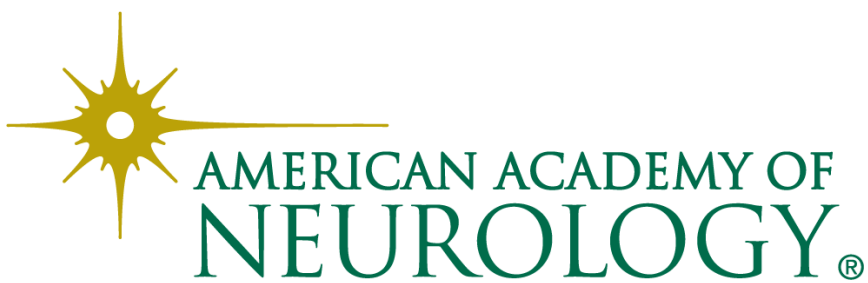

